\title{
Penanganan Anak ISIS dalam Perspektif Hukum Indonesia
}

\author{
Mohamad Rapik ${ }^{\star}$, Bunga Permatasari ${ }^{\star \star}$ \\ Fakultas Hukum Universitas Jambi \\ ^m.rapik@unja.ac.id

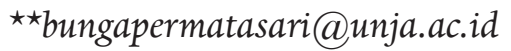

\begin{abstract}
The involvement of children in the ISIS network has left a complex problem in the legal discourse in Indonesia, including how to deal with children involved in this terrorism network. This article aims to expose the problem of children in conflict with the law in the crime of terrorism. Due to this problem, the Indonesian government is often faced a dilemma between the neccessity to apply serious efforts to eradicate terrorism and the obligation to guarantee a protection to the children. Through a juridicalnormative approach, focusing on ISIS children, this article demonstrates that one of the problems in dealing with children involved in terrorism networks lies in the vagueness of the rules addressing the children involved in this terrorism network as well as its implementation by the government. Therefore, this article argues that in order to be able to deal with children involved in terrorism networks, some of the legal instruments concerning the issue, especially the law on terrorism and the laws of children in conflict with the law as long as terrorism is concerned needs to be revised just to accommodate this issue in a more obvious normsto actually maintain a balance between the responsibility to protect the children and the need to preserve stability of the nation and state. Under the new revised laws, the government is hoped to work with and apply the provisions regarding children in conflict with the law in the case of terrorism crimes in the frame of justice and protection for children.
\end{abstract}

Keywords: ISIS children; terrorism; treatment; Indonesian law. 


\section{Abstrak}

Keterlibatan anak dalam jaringan ISIS menyisakan permasalahan yang kompleks dalam wacana hukum di Indonesia berikut penanganan anak yang terlibat dalam jaringan terorisme ini. Artikel ini bertujuan untuk memaparkan masalah penangangan anak yang berkonflik dengan hukum dalam tindak pidana terorisme. Terkait hal ini, pemerintah Indonesia seringkali dihadapkan pada dilema antara upaya serius untuk memberantas tindak pidana terorisme dan kewajiban untuk memberikan perlindungan kepada anak. Melalui pendekatan yuridis-normatif, dengan mengambil kasus anak-anak ISIS, artikel ini memperlihatkan bahwa salah satu masalah yang ditemui dalam penanganan anak yang terlibat dalam jaringan terorisme terletak pada ketidakjelasan aturan sejauh menyangkut masalah penangangan anak tersebut berikut pelaksanaannya di lapangan oleh negara. Oleh karena itu, artikel ini berargumen bahwa untuk bisa menangani anakanak yang terlibat dalam jaringan terorisme, beberapa instrumen hukum yang mengatur masalah ini, utamanya undang-undang terorisme dan undang-undang yang berhubungan dengan anak yang berkonflik dengan hukum harus direvisi guna mengakomodasi permasalahan ini secara lebih jelas yang benar-benar menjaga keseimbangan antara kepentingan anak dan kepentingan bangsa dan negara. Selanjutnya, pemerintah sejatinya mampu mengacu dan menerapkan segala ketentuan hukum yang berlaku mengenai anak yang berkonflik dengan hukum dalam kasus tindak pidana terorisme sebagaimana yang diakomodasi dalam undang-undang tersebut.

Kata kunci: anak ISIS; terorisme; penanganan; hukum Indonesia.

\section{A. Pendahuluan}

Artikel ini membahas kedudukan anak dalam jaringan Islamic State of Irak and Suriah (ISIS) dan penanganannya menurut hukum yang berlaku di Indonesia. Sebuah laporan menunjukkan bahwa eskalasi anak yang terlibat dalam jaringan terorisme mengalami peningkatan akhir-akhir ini dan diduga kuat merupakan "korban" indoktrinasi dari kerabat dekat mereka, terutama dari orang tua mereka yang sudah berafiliasi dengan kelompok radikal. ${ }^{1}$ Fenomena ini menjadi

1 Khariroh Maknunah, "Penanganan Anak dalam Tindak Pidana Terorisme", Kertas Kebijakan RUU Nomor 15 Tahun 2003 tentang Penetapan Peraturan Pemerintah Pengganti Undang-Undang Nomor 1 Tahun 2002 tentang 
tantangan baru di dunia hukum lantaran di satu sisi anak memiliki hak-hak khusus dan perlakuan yang berbeda dari orang dewasa. Namun di sisi lain, disadari pula bahwa terorisme merupakan kejahatan luar biasa yang bisa berdampak pada kerusakan material dan hilangnya nyawa berskala besar. Dalam artikel ini, pembahasan kedudukan dan penanganan anak dalam jaringan ISIS dibatasi dalam ranah hukum pidana saja.

ISIS, dalam bahasa Indonesia disebut Negara Islam di Irak dan Suriah, ${ }^{2}$ merupakan gerakan atau kelompok ekstremis yang dibentuk pada 9 April 2013 di bawah pimpinan Abu Bakar al-Baghdadi. Organisasi ini dipandang sebagai transformasi al-Qaida dalam bentuk yang lebih radikal, yang menjadikan Irak dan Suriah sebagai pusat (the land of jihad) dari negara Islam yang didirikan. Semula jihad yang dipropagandakan mengajak diaspora Muslim di berbagai belahan dunia untuk mendukung perjuangan mereka bahkan melakukan jihad ke Irak dan Suriah. Dalam perkembangannya, gerakan ini tidak lagi harus di Irak atrau Suriah, melainkan menyebar ke berbagai negara. ${ }^{3}$

Munculnya ISIS telah melahirkan gerakan baru sejauh menyangkut kejahatan terorisme. ISIS telah digolongkan sebagai organisasi teroris yang berkedudukan di Suriah, ${ }^{4}$ yang tujuan utamanya adalah menegakkan kedaulatan agama yang mereka sebut sebagai Khilafah. ${ }^{5}$

Pemberantasan Tindak Pidana Terorisme Menjadi Undang-Undang, Indonesia Civil Society Against Violent Extremism, hlm. 1, http://csave. org/wp-content/ uploads / 2018/06/ Penanganan-Anak-Dalam-TindakPidana-Terorisme.pdf?x96255, diakses 26/11/2020.

2 Jusuf Kalla, "NIIS dan Janji Surga", harian Kompas, 12/12/2018. Dalam artikel ini, istilah ISIS lebih dipilih untuk digunakan dengan mempertimbangkan penyebutannya yang telah begitu popular bila dibandingkan NIIS.

3 Najamuddin Khairur Rijal, "Eksistensi dan Perkembangan ISIS: Dari Irak Hingga Indonesia”, Jurnal Ilmiah Hubungan Internasional, 13, 1 (20170, hlm. 48.

4 SahidHM, "Contesting Caliphate: Opposition of Indonesian Fundamentalist Groups to ISIS Caliphate,” Journal of Indonesian Islam, 8, 2 (2014), hlm. 186.

5 Makmum Rasyid, Hizbut Tahrir Indonesia: Gagal Faham Khilafah (Ciputat: Pustaka Compass, 2016), hlm. 27; Zuly Qodir, HTI dan PKS Menuai Kritik: Perilaku Gerakan Islam Politik Indonesia (Yogyakarta: Universitas Muhammadiyah, 2013). 
ISIS telah menarik banyak kalangan dari masyarakat Islam untuk bergabung mewujudkan cita-cita idealnya. Banyak yang percaya bahwa cita-cita tersebut merupakan janji yang benar, baik secara teologis, historis, maupun politis. ISIS dianggap sebagai jalan pintas meraih apa yang mungkin disebut sebagai cita-cita yang dianggap mulia, yaitu menguasai dunia dengan cita-cita Islam yang darinya akan terwujud peradaban dalam sistem khilafah.Kalaupun cita-cita tidak memungkinkan untuk dicapai, paling tidak para anggota ISIS, yang sudah terdoktrin itu, bersedia meruntuhkan sistem dalam negeri yang dianggap thoghut. ${ }^{6}$ Tercatat sejumlah anggotanya yang berasal dari sejumlah negara, baik dari negara-negara berpenduduk Muslim maupun dari negara-negara yang sebenarnya bukan merupakan negara Islam seperti Jerman, Inggris, Australia, maupun Amerika. Indonesia telah menjadi salah satu negara yang menjadi sasaran utama rekrutmen anggota ISIS. Gelombang masyarakat yang bergabung dengan ISIS ini pun bukan semata perorangan, namun juga dalam bentuk kelompok, baik keluarga maupun kelompok kecil masyarakat,mulai dari orang dewasa, remaja, hingga maupun anakanak, baik laki-laki maupun perempuan. ${ }^{7}$

Bergabungnya sejumlah kalangan ke dalam ISIS tentu saja menimbulkan masalah baru bagi suatu kelompok maupun negara. Kebergabungan dengan ISIS berarti sama saja dengan mendeklarasikan diri untuk berada pada satu pihak dan meninggalkan pihak lain. Beberapa masyarakat Indonesia dilaporkan telah mendeklarasikan diri keluar dari Negara Kesatuan Republik Indonesia dan menyatakan

6 Quinton Temby, Terrorism In Indonesia After "Islamic State" (Singapore: ISEAS-Yusof Ishak Institute, 2020), hlm. 10.

7 Direktur Jenderal Imigrasi Ronny F. Sompie mengatakan, total sebanyak 234 orang Daftar Pencarian Orang (DPO) dari kepolisian yang datanya dimasukkan ke Ditjen Imigrasi. Dari jumlah itu, 91 orang DPO terkait ISIS, dan 143 DPO terkait terorisme. Khusus 91 DPO terkait dengan ISIS, delapan di antaranya merupakan warga negara asing yang terdiri dari satu warga negara Algeria, dua warga negara Kuwait, dua warga negara Saudi Arabia, satu warga negara Suriah, dan dua warga negara Turki. Sedangkan dari Indonesia, DPO yang terkait ISIS sebanyak 83 orang. Kifly Arafat Samu, "Status Hukum Warga Negara Indonesia yang Terlibat dalam Organisasi Teroris Internasional”, Lex Et Societatis, 6, 10 (2018), hlm. 80. 
diri secara sukarela bergabung dengan ISIS. ${ }^{8}$

Seiring dengan berjalannya waktu, ISIS ternyata mengalami kekalahan di mana-mana, termasuk di pusat perkembangannya, yaitu Suriah. Dalam banyak pertempuran, banyak anggota kelompok ini yang tewas, termasuk beberapa kombatan asal Indonesia. Kekalahan ini menyebabkan beberapa anggota keluarga memutuskan untuk kembali ke tanah air masing-masing. Tidak terkecuali, anggota yang merupakan eks WNI menyatakan niatnya untuk rujuk dengan Negara Kesatuan Republik Indonesia. Merespons masalah ini, sikap negara-negara menjadi berbeda-beda: sebagian menerima, sebagian lagi menolak. Indonesia termasuk negara yang menolak kembalinya anggota ISIS ke pangkuan tanah air. Bahkan beberapa waktu sebelum pengumuman resmi dari Pemerintah Republik Indonesia menyangkut penolakan negara terhadap warga ISIS, Menteri Agama sempat melontarkan pernyataan kontroversial yang intinya bermaksud (atas nama pemerintah) untuk menerima kembali anggota ISIS eks WNI. Pernyataan ini sempat menimbulkan reaksi dan kecaman keras dari kebanyakan masyarakat Indonesia. ${ }^{9}$ Pada akhirnya, keputusan Pemerintah Republik Indonesia untuk tidak menerima anggota ISIS tersebut menyudahi wacana kontroversi Menteri Agama tersebut.

Kendati keputusan untuk menolak kepulangan anggota ISIS sudah final kala itu, Pemerintah memberikan pengecualian kepada anak-anak di bawah 10 tahun. ${ }^{10}$ Keputusan ini tentu tidak lepas dari kontroversi mengingat indoktrinasi terorisme dari organisasi ISIS

8 Tercatat sekitar 700 hingga lebih dari 1000 orang Indonesia hijrah ke Suriah untuk begabung dengan pasukan al-Qaidah atau lebih banyak lagi bergabung dengan ISIS. Temby, Terrorism In Indonesia, hlm. 10. Lihat juga Grover Rondonuwu, "Memulangkan Pejuang ISIS Eks WNI, Dilema Hukum dan Kemanusiaan”, https://www.kompasiana.com/ grover / 5e3c96c2d541df7bcd6d9f62 / memulangkan-pejuang-isis-eks-wnidilema-hukum-dan-kemanusiaan?page $=$ all\#sectionall, $7 / 2 / 2020$, diakses $25 / 2 / 2020$.

9 Rondonuwu, "Memulangkan Pejuang ISIS Eks WNI".

10 Lihat Nurina Vidya Hutagalung, "Penanganan Anak Simpatisan ISIS", https: / / kolom.tempo.co/ read/1308827 / penanganan-anak-simpatisan-isis, $18 / 02 / 2020$, diakses $25 / 02 / 2020$. 
besar kemungkinan juga memapar anak-anak tersebut. ${ }^{11}$

Masalah keterlibatan anak dalam jaringan terorisme, seperti ISIS, belum dielaborasi dengan baik dalam perundang-undangan di Indonesia. Hal ini boleh jadi disebabkan karena fenomena anak yang terlibat dalam jaringan terorisme dapat dikatakan merupakan fenomena yang baru dalam wacana hukum di Indonesia. UndangUndang di Indonesia tidak mengatur masalah ini secara rinci dan tegas sehingga dapat menimbulkan kegamangan dalam menangani anak yang terlibat dalam jaringan terorisme. Akibatnya, hak dari anak-anak tersebut untuk mendapatkan jaminan kepastian, keadilan, dan kemanfaatan hukum menjadi terabaikan. Kedudukan anak seperti ini perlu dikaji secara serius, mengingat masalah baru ini telah menimbulkan problematika hukum yang cukup pelik di Indonesia.

Pembahasan perspektif hukum Indonesia terkait penanganan anak jaringan ISIS ${ }^{12}$ dalam artikel ini akan dilanjutkan dengan uraian tentang anak dalam jaringan ISIS dan penyikapannya oleh pemerintah

11 Pada Mei 2019, beredar video yang menampilkan sejumlah anak-anak melakukan latihan militer dan aksi pembakaran paspor untuk bergabung dengan ISIS. Aksi tersebut dipimpin oleh seorang milisi dari Malaysia. Lihat Indonesia Morning Show Net, "Menggunakan Senjata, Anakanak Bocah ini Latihan Militer ISIS", https://www.youtube.com/ watch?v=14yVDKSdVNU, 24/5/2016, diakses 03/03/2020.

12 Artikel ini secara ringkas menggunakan istilah anak ISIS, sekalipun dalam pembahasan digunakan secara bergantian dengan misalnya anak dalam jaringan ISIS dan anak berkonflik dengan hukum. Penggunaan istilah Anak ISIS terinspirasi dari frasa ISIS Children, Child Soldiers atau bahkan Islamic State Children (Conrad Nyamutata, "Young Terrorists or Child Soldiers? ISIS Children, International Law and Victimhood," Journal of Conflict and Security Law, 25, 2 [2020]: 236-61; Aleksandar Paṡagić, "Between Child Soldiers and Terrorists: Reintegrating Child Members of the Islamic State," Journal for Deradicalization, 20 [2019], hlm. 111). Istilah Anak ISIS di sini dimaksudkan sebagai anak yang terlibat dalam jaringan ISIS, terlepas keterlibatannya itu karena dorongan akan kesadaran atau pemahamannya sendiri ataukah di luar kesadaran, pemahaman, dan keuasannya. Sebab, bisa jadi memang anak menjadi bagian dari ISIS karena dorongan pemahaman dan kesadarannya sendiri, atau setidaknya menyetujuinya, yang barangkali disebabkan doktrin yang diterimanya, namun juga tidak menutup kemungkinan menjadi bagian dari ISIS karena semata-mata keharusan ikut dengan orang tuanya tanpa ada kesadaran atau pemahaman, yang bahkan bisa jadi secara naluriah sebenarnya menolaknya (misalnya soal kekerasan). 
Indonesia. Uraian ini dimaksudkan untuk memaparkan bagaimana anak dilibatkan dalam jaringan ISIS dan bagaimana pemerintah kemudian menyikapinya. Bagian berikutnya membahas tentang perspektif hukum dalam penanganan anak jaringan ISIS. Pada bagian ini diperlihatkan bagaimana keberpihakan hukum terhadap anak yang berkonflik dengan hukum, dan instrumen hukum yang ada relatif belum mengantisipasi keterlibatan anak dalam jaringan terorisme.

\section{B. Anak ISIS dan Sikap Pemerintah Indonesia}

Sejak terjadinya peristiwa bom bunuh diri di Surabaya pada $13 / 5 / 2018$, orang mulai menyadari bahwa saat ini anak sudah masuk dalam pusaran terorisme. Fenomena baru ini menimbulkan masalah baru menyangkut kejahatan extra ordinary crime di Indonesia. ${ }^{13}$ Keterlibatan anak dalam tindak pidana terorisme menyadarkan banyak pihak bahwa radikalisasi telah terjadi sejak dini.

Keterlibatan anak dalam tindak pidana terorisme atau jaringan terorisme beberapa tahun belakangan mendapatkan perhatian yang serius, baik bagi para pembuat kebijakan maupun masyarakat luas. Bahkan Resolusi 2427 (2018) Dewan Keamanan Perserikatan BangsaBangsa menggarisbawahi pentingnya memberikan perhatian serta perlakuan khusus bagi anak-anak yang terlibat dengan jaringan kelompok bersenjata maupun anak-anak yang melakukan tindak pidana terorisme. Hal ini mendorong para pembuat kebijakan untuk menyusun standar-standar bagi perlindungan anak dan sistem pemidanaan melalui ekosistem counter-terorisme. ${ }^{14}$

Jorgensen, sebagaimana dikutip Akbar Mohammad Arief, melaporkan bahwa seorang anak dari Inggris bernama Shamima Begum telah meninggalkan rumahnya di usia 15 tahun dan

13 Sarlito Wirawan Sarwono, Terorisme di Indonesia dalam Tinjauan Psikologi (Ciputat: Pustaka Alvabet, 2012).

14 Sandra Krähenmann dan Paulien Vandendriessche, "From Child Soldier to Child 'Terrorist': Safeguarding Innocence from Counter-terrorism", https: / / blogs.icrc.org/law-and-policy / 2019/11/20/ child-soldier-counterterrorism/, 20/11/2019, diakses 22/06/2020. 
memilih untuk berangkat ke Suriah untuk bergabung dengan ISIS. Keputusan Shamima untuk bergabung dengan ISIS dipercaya lantaran terpengaruh propaganda-propaganda ISIS yang berisi janjijanji manis mengenai masa depan yang dijamin di dunia maupun akhirat nanti. ${ }^{15}$ Selain Shamima, terdapat anak-anak lain yang menjadi teroris dengan motivasi tertentu, di antaranya ialah karena ingin mendapatkan ketenaran dan rasa hormat dari lingkungannya. Bahkan selain dengan sukarela, sejumlah anak dilaporkan telah diculik penculikan dan dipaksa bergabung dengan ISIS. Laporan lain menyebutkan sebanyak 20.000 anak yang berasal dari Uganda, misalnya, menjadi teroris anak lantaran dipaksa. ISIS diduga kuat telah melakukan penculikan ribuan anak dari berbagai daerah untuk dijadikan teroris. ${ }^{16}$

Sidney Jones membeberkan bahwa gerakan terorisme yang didalangi ISIS ini telah merambah berbagai tempat di Indonesia untuk melakukan ekspansi dan mentransformasi masyarakat setempat menjadi ekstremis. Namun, belakangan, gerakan ISIS ini telah mengubah taktik: menyasar perempuan dan anak-anak untuk direkrut dalam aksi serangan serangan bom bunuh diri. Jones menuturkan betapa berbahayanya indoktrinasi yang telah dilakukan oleh kelompok ekstremis yang mengakibatkan enam anggota keluarga terdiri dari ayah, ibu, dua anak laki-laki, dan dua anak perempuan yang masih berusia 12 dan sembilan tahun, melakukan aksi serangan terorisme di sebuah gereja di Surabaya, Jawa Timur dengan cara meledakkan diri. ${ }^{17}$ Ini semua tidak lepas dari kontribusi ISIS yang senantiasa berupaya menanam bibit radikal di kalangan masyarakat Indonesia, terutama perempuan dan anak-anak. ${ }^{18}$

15 Akbar Mohmmad Arief, “Terorisme dan Anak-Anak", https: / / projectchild. ngo/blog/2020/01/15/terorisme-dan-anak-anak/, 15/01/2020, diakses $04 / 03 / 2020$.

16 Akbar, "Terorisme dan Anak-Anak."

17 Kirsten E. Schulze, "The Surabaya Bombings and the Evolution of the Jihadi Treat in Indonesia,” CTC Sentinel, 11, 6 (2018), hlm. 1.

18 Sidney Jones, "How ISIS Has Changed Terrorism in Indonesia," The New York Times, https://www.nytimes.com/2018/05/22/opinion/isisterrorism-indonesia-women.html, 22/05/2018, diakses 26/11/2020. 
Menurut Jessica Trisko Darden, generasi muda adalah sumber vital untuk mendukung kelompok terorisme dengan peran yang bermacam-macam, mulai dari juru masak hingga pasukan bersenjata. Akan tetapi cara perekrutan anak-anak muda itu dilakukan dengan berbagai cara. Dalam banyak hal, anak-anak yang bergabung dengan kelompok teroris itu adalah karena mereka ditipu, diperdagangkan, diculik, atau direkrut secara paksa. Ada juga yang bergabung dengan kelompok teroris secara sukarela karena godaan identitas berbasis kelompok ini seperti persepsi eksklusi, keluhan, atau ancaman budaya, janji stabilitas ekonomi, prospek ketenaran, kemuliaan, atau rasa hormat, serta koneksi pribadi, termasuk jaringan keluarga dan pertemanan. Kerentanan anak-anak terhadap perekrutan teroris dapat dipengaruhi oleh banyak faktor, termasuk kedekatan geografis mereka dengan kelompok teroris, kerentanan ekonomi, persepsi marjinalisasi sosial atau politik, paparan jaringan sosial yang permisif, dan paparan propaganda ekstremis. Akan tetapi, kepentingan relatif dari faktor-faktor ini bervariasi secara individu dan sesuai dengan konteks lokal. ${ }^{19}$

Di Indonesia, fenomena anak ISIS ini terkuak ke publik terutama setelah beredarnya video seorang perempuan belia bernama Nada Fedulla. Nada, yang bercita-cita menjadi seorang dokter terpaksa meninggalkan sekolahnya karena harus mengikuti ayahnya yang memboyong anggota keluarganya untuk bergabung dengan ISIS di Suriah. Menurut penuturannya, ia dulu tidak lain adalah anak-

19 Jessica Trisko Darden, Tackling Terrorists' Exploitation of Youth (Amerika: American Enterprise Institute, 2019), hlm. 3. Cara lain yang menjadi modus perekrutan ialah menggunakan jasa teknologi secara daring. Sebagai pengguna aktif internet, anak-anak berada dalam risiko yang tinggi sebagai korban dunia maya. Biasanya ada dua cara yang digunakan pelaku untuk merekrut anak-anak ke dalam jaringan terorisme. Pertama, dengan metode grooming, yaitu cara perekrutan dengan modus membangun relasi atas dasar saling percaya (relatonship of trust) antara calon korban dan pelaku. Kedua, dengan cara menyaru iklan, yang dilakukan dengan cara melacak perilaku umum pengguna internet, kemudian memasukkan iklan yang bersifat propaganda kepada para pengguna tersebut. United Nations Office on Drugs and Crime, Handbook on Children Recruited and Exploited by Terrorist and Violent Extremist Groups: The Role of the Justice System (Vienna: United Nations, 2017), hlm. 12-13. 
anak yang sama dengan yang lain yang bercita-cita menjadi dokter, sampai kemudian diboyong ayahnya ke Suriah. Selama di Suriah, Nada menuturkan kepada koresponden BBC Timur Tengah, Quentin Sommerville, bahwa ia kerap menjadi saksi kekejaman ISIS, dan melihat dengan mata kepala sendiri bagaimana pengikut ISIS menyiksa orang-orang di jalan, atau membunuhnya. Keluarga Nada adalah salah satu dari mereka yang termakan propaganda ISIS. Banyak negara yang menolak keluarga dan eks-anggota ISIS kembali pulang karena khawatir bisa melahirkan sel-sel teroris baru. Nada adalah salah satu dari korban propaganda ISIS tersebut yang ditolak kembali ke Indonesia. ${ }^{20}$

Keterlibatan anak-anak dalam aksi terorisme menjadi kontroversial terkait kedudukan anak-anak tersebut, apakah korban atau pelaku. Fakta bahwa hukum di Indonesia telah memberi hak istimewa bagi anak sejauh menyangkut anak yang berkonflik dengan hukum, namun fakta juga menunjukkan bahwa tindak pidana terorisme sangat membahayakan dan bahkan mengakibatkan hilangnya nyawa dan kerugian yang besar. Tindak pidana terorisme merupakan kejahatan luar biasa.

Terorisme yang terjadidi beberapa tempat di Indonesia, baik yang dilakukan oleh orang Indonesiaataupun dilakukan oleh orang luar, selalu menyisakan kepanikan dan korban yang luas. Karena itu, menurut Muladi, seperti dikutip Ahmad Mahyani, tindak pidana terorisme harus ditangani dengan carayang luar biasa, karena empat alasan: aksi terorisme berbahaya dan mengancam HAM untuk hidup bebas dari rasa takut; kemungkinan diigunakannya senjata pemusnah modern; terjadi sinergi organisasi terorisme nasional dengan internasional; dan target bersifat random cenderung mengorbankan masyarakat umum. ${ }^{21}$

Menyikapi pulangnya WNI eks-ISIS, pemerintah Indonesia

20 BBC News Indonesia, "Bisakah Kamu Memaafkan Ayah yang Jadi Anggota ISIS?”, https: / /www.youtube.com/watch?v=GbjMdAFZhJk, 5/2/2020, diakses 26/11/2020.

21 Ahmad Mahyani, "Perlindungan Hukum Anak Sebagai Pelaku Terorisme," Jurnal Hukum Magnum Opus, 2, 1 (2019), hlm. 47. 
menujukkan sikap yang kurang pasti, ditandai dengan kurang koordinasi antara Pemerintah dengan pihak otoritas di Suriah. Pada 2019, majalah Tempo melaporkan bahwa otoritas Kurdistan Suriah yang hendak membantu pemulangan pengungsi ISIS asal Indonesia kurang mendapatkan kesempatan berkomunikasi dengan Pemerintah Indonesia. Komunikasi terakhir dengan Pemerintah Indonesia terjadi dua tahun lalu. ${ }^{22}$

Seperti telah disebutkan di Pendahuluan, Pemerintah Indonesia akhirnya bersedia memulangkan. Sikap ini bisa dipahami sebagai langkah yang sulit di tengah kekhawatiran di kalangan masyarakat menyangkut keamanan dan paparan radikalisme yang kemungkinan besar dibawa oleh anggota eks ISIS. Dalam situasi tersebut, pemerintah memutuskan untuk menerima anak yang berusia di bawah 10 tahun saja. ${ }^{23}$ Sikap ini jelas menimbulkan permasalahan hukum karena Undang-undang Perlindungan Anak jelas menyebutkan bahwa anak itu mencakup usia di atas 10 tahun, selama belum mencapai usia 18 tahun. Dalam undang-undang itu disebutkan juga 15 jenis anak yang harus diberi perlindungan khusus. Di antaranya adalah "anak dalam situasi darurat" dan "anak korban jaringan terorisme”. Pada kondisi anak WNI eks ISIS, dua kategori tersebut terpenuhi. Karena itu, keputusan pemerintah yang hanya akan memulangkan anak dalam batas usia dan kondisi tertentu bertentangan dengan hukum yang berlaku.

\section{Keberpihakan Hukum terhadap Anak ISIS}

Secara normatif, merujuk asas nasional aktif sebagaimana terdapat pada Pasal 5 ayat (2) Kitab Undang-undang Hukum Pidana (KUHP), ketentuan pidana dalam perundang-undangan Indonesia diterapkan bagi warga negara yang berada di luar Indonesia melakukan perbuatan yang oleh suatu ketentuan pidana dalam perundangundangan Indonesia dipandang sebagai kejahatan, sedangkan menurut perundang-undangan negara dimana perbuatan tersebut

22 Majalah Tempo, “Nestapa di Negeri Syam”, https://majalah.tempo.co/ $\mathrm{read} / 157863 /$ nestapa-di-negeri-syam, 22/06/2019, diakses 25/11/2020.

23 Hutagalung, "Penanganan Anak Simpatisan ISIS". 
jikadilakukan, diancam dengan pidana. Artinya, sekalipun suatu perbuatan dilakukan di luar wilayah Indonesia, tindakan yang dilakukan oleh WNI eks ISIS tersebut tetap dapat diadili menurut hukum yang berlaku Indonesia.

Pasca diundangkannya Undang-Undang Nomor 11 tahun 2012 tentang Sistem Peradilan Pidana Anak (UU SPPA), paradigma mengenai pengadilan anak mengalami perubahan yang signifikan. Jika sebelumnya melalui Undang-Undang Nomor 3 Tahun 1997 tentang Pengadilan Anak (UU PA), model penanganan anak disamakan dengan orang dewasa, dengan model retributive justice, di mana dalam hal ini penghukuman dan pembalasan dijadikan sebagai pilihan utama, UU SPPA ini memberikan keistimewaan kepada anak dengan memisahkan dan membedakannya dari peradilan orang dewasa. UU SPPA mengusung paradigma bahwa anak-anak yang berhadapan dengan hukum sejatinya adalah "korban" ${ }^{24}$ kejahatan, dan bukannya pelaku. Karena itu, peradilan anak sebisa mungkin

24 Pengertian "korban" di sini harus dipahami dalam sudut pandang filosofispsikologis. Paradigma bahwa anak yang berhadapan dengan hukum adalah korban berangkat dari kenyataan bahwa anak merupakan individu yang dianggap belum matang, baik secara fisik maupun psikis. Dengan begitu setiap tindakannya tidaklah murni atas dorongan keinginan dan inisiatifnya (baca mensrea), melainkan karena kecendrungan mencontoh. Karena ketidakmampuan bertanggung jawab atas setiap perbuatannya, kesalahan yang dilakukan anak juga dianggap tidak murni dari dirinya. Bambang Santoso, Soehartono, dan Muhammad Rustamaji, "Unearthing the Philosophical Roots of Pancasila on Distinctive Legal Treatments for Children in Conflict with the Law," Yustisia, 6, 2 (2017), hlm. 290. UU SPPA memberi batasan anak yang bisa bertanggung jawab, yang disebut sebagai anak yang berkonflik dengan hukum. Secara yuridis-normatif, anak yang berkonflik dengan hukum adalah Anak yang diduga melakukan tindak pidana dalam rentang usia antara 12 tahun dan belum mencapai usia 18 tahun (Pasal 1 ayat 3 UU SPPA). Adapun Anak korban adalah anak yang mengalami penderitaan fisik, mental, dan/atau kerugian ekonomi yang disebabkan oleh tindak pidana (Pasal 1 ayat 4 UU SPPA). UU SPPA juga memberi batasan bahwa anak yang dapat dikenai pidana hanya anak yang berusia 14 tahun namun belum mencapai usia 18 tahun. Sementara anak yang belum mencapai usia 14 tahun hanya dapat dikenai sanksi tindakan (Pasal 69 ayat 2). Adapun anak yang berusia di bawah 12 tahun yang melakukan tindak pidana, maka anak tersebut diserahkan kembali kepada orang tua / wali atau diikutsertakan dalam program pendidikan, pembinaan, dan pembimbingan di instansi pemerintah atau LPKS (Pasal 21 ayat 1). 
dilakukan dalam bingkai restorative jusice dengan cara diversi (di luar pengadilan). Paradigma ini berlaku untuk semua tindak pidana termasuk terorisme. ${ }^{25}$

Pada 3 Maret 2020, sejumlah perwakilan tinggi dari Indonesia, Malaysia, Maldives dan Filipina berkumpul di Bali yang bertajuk The Bali Call for Action for the Implementation of the UNODC Roadmap on Children Associated with Terrorism and Violent Extremist Groups. Pertemuan itu menyepakati bahwa anak-anak yang terasosiasi, atau terpengaruh, dengan kelompok teroris atau ekstrimis sejatinya adalah korban dan seharusnya diperlakukan dengan layak menurut kepentingan anak itu sendiri yang menjunjung keselamatan fisik maupun psikologis mereka dan memerhatikan kesehatan, harga diri, rasa hormat mereka melalui pendekatan yang memerhatikan sensitivitas mereka. ${ }^{26}$

Edwin Partogi Pasaribu dari Lembaga Perlindungan Saksi dan Korban (LPSK) berargumentasi bahwa anak yang terlibat dalam jaringan teroris ISIS bukanlah korban. Dia berkeyakinan bahwa korban tiada lain adalah korban dari suatu tindak pidana. Adapun dalam konteks anak menjadi anggota ISIS kriterita tersebut tidak ada. Edwin tampaknya meyakini bahwa dalam konteks hukum pidana korban tiada lain adalah korban yang mengalami suatu penderitaan akibat dari suatu perbuatan jahat. Dalam konteks di mana anak menjadi anggota teroris ISIS, mereka tidak dapat dikatakan sebagai korban sekalipun diajak oleh orang tuanya. Akibatnya, mereka tidak selayaknya mendapatkan perlindungan korban kecuali korban suatu tindak pidana, itu pun setelah melalui proses hukum. Tetapi Edwin

25 M. Nasir Djamil, Anak Bukan Untuk Dihukum Catatan Pembahasan UU Sistem Peradilan Pidana Anak (UU-SPPA) (Jakarta: Sinar Grafika, 2013), hlm. 4. Hal ini diperkuat oleh laporan United Nations Office on Drugs and Crime, bahwa anak-anak yang direkrut dan dieksploitasi oleh kelompok teroris adalah korban kejahatan, yang dilarang oleh Konvensi Hak Anak. UNODC, Handbook on Children Recruited, hlm. 40.

26 United Nations Office on Drugs and Crime, "The Bali Call for Action for the Implementation of the Unodc Roadmap on Children Associated with Terrorist and Violent Extremist Groups", https://www.unodc.org/ $\mathrm{pdf} /$ criminal_justice/endVAC/The_Bali_Call_for_Action.pdf, diakses $23 / 09 / 2020$. 
menyarankan masalah anak anggota ISIS seharusnya dilihat secara kontekstual, apakah mereka menjadi anggota ISIS secara sukarela, ikut-ikutan, atau dengan cara paksaan. Karena itu penanganan anak yang menjadi anggota ISIS harus disesuaikan dengan motif tersebut. $^{27}$

Konteks pertanggungjawaban pidana terorisme dapat merujuk pada pendapat Abdul Wahid dkk., tentang hierarki organisasi terorisme. Menurutnya, untuk mengetahui tentang pertanggungjawaban pidana dalam kejahatan terorisme paling tidak harus diketahui tentang hierarki organisasi terorisme. ${ }^{28}$ Dengan mengutip pendapat Faser dan Fulton, Wahid, dkk. menguraikan bagaimana organisasi terorisme mengorganisir diri ke dalam empat hierarki. Pertama, merupakan posisi puncak, dipegang oleh kelompok elit yang memegang kendali aksi dan menyusun rencana dan strategi. Kedua, merupakan kader aktif yang bertugas melaksanakan aksi aksi-aksi terorisme di lapangan. Ketiga, merupakan bagian internal yang memiliki jumlah paling banyak. Mereka adalah para pendukung aktif. Tugas utamanya biasanya berkenaan dengan penyediaan fasilitas dan logistik bagi setiap aksi di lapangan. ${ }^{29}$

Berdasarkan hierarki tersebut, sejauh menyangkut pertanggungjawaban pidana, dapat disimpulkan bahwa orang yang menempati hierarki pertama hukumannya lebih berat dibandingkan orang yang berada pada hierarki yang kedua, dan demikian untuk selanjutnya. Sementara orang yang berada dalam hierarki keempat yang sejatinya merupakan pendukung pasif ini, menurut Wahid, tidak bisa begitu saja dianggap mendukung terorisme dan dijatuhi pidana karena mereka sebenarnya adalah orang baik-baik yang hanya dimanfaatkan dan digalang oleh para teroris tanpa mereka sadari. ${ }^{30}$ Nalar ini sangat

27 Beritasatu.Com, "LPSK: Anak dan Istri Eks ISIS Bukan Korban”, https: / / www.beritasatu.com/yuliantino-situmorang/nasional/600052/lpsk-anakdan-istri-eks-isis-bukan-korban, 13/02/2020, diakses 23/09/2020.

28 Abdul Wahid, Sunardi, dan Muhammad Imam Sidik, Kejahatan Terorisme: Perspektif Agama, HAM, dan Hukum (Bandung: Refika Aditama, 2004), hlm. 96.

29 Wahid, dkk., Kejahatan Terorisme, hlm. 96-97.

30 Wahid, dkk., Kejahatan Terorisme, hlm. 96-97. 
bisa dipakai dalam mengukur pertanggungjawaban pidana anak terkait keterlibatannya dalam organisasi teroris ISIS.

Kedudukan anak menjadi sangat spesial terutama dengan adanya undang-undang khusus yang mengatur mengenai perlindungan anak. Anak dipandang memiliki kedudukan penting dari suatu elemen bangsa karena mereka tiada lain adalah generasi penerus bangsa maupun negara. Oleh karena itu, negara berusaha memastikan bahwa setiap anak memperoleh kesempatan dan kebebasan agar dapat tumbuh dan berkembang dengan optimal, baik fisik, psikis, sosial, maupun spiritual. Negara dan semua elemen yang ada di dalamnya dituntut untuk memberikan perlindungan secara maksimal serta memenuhi hak-haknya tanpa membedakan satu dengan lainnya. ${ }^{31}$

Negara menjamin hak asasi manusia setiap warga negara, tidak terkecuali hak asasi anak. Jaminan tersebut tertuang dalam UndangUndang Dasar Negara Republik Indonesia Tahun 1945, termasuk dalam sejumlah peraturan perundang-undangan yang berlaku di Indonesia. Jaminan ini diperkuat dengan diratifikasi Konvensi Internasional mengenai Hak Anak melalui pengesahan Keputusan Presiden Nomor 36 Tahun 1990 tentang Pengesahan Convention on The Rights of the Child atau Konvensi Tentang Hak-Hak Anak. Konvensi ini mengatur beberapa prinsip dasar anak yakni prinsip non diskriminasi, prinsip kepentingan terbaik bagi anak (best interest for children), prinsip atas hak hidup, keberlangsungan dan perkembangan serta prinsip atas penghargaan terhadap pendapat anak. ${ }^{32}$

Oleh karena itu, baik pemerintah, pemerintah daerah, maupun masyarakat dan keluarga (terutama orang tua) wajib memberikan perlindungan dan jaminan akan hak asasi anak menurut fungsi dan tanggungjawabnya masing-masing. Anak-anak juga harus dijamin rasa keamanannya dari setiap bentuk kejahatan, seperti penyiksaan, kejahatan seksual, eksploitasi, maupun perdagangan anak. Untuk itu diperlukan upaya lebih serius dari pemerintah maupun pemerintah

31 Penjelasan Undang-Undang Perlindungan Anak.

32 United Nations Human Rights Office of the High Commissioner, "Convention on the Rights of the Child", https://www.ohchr.org/en/ professionalinterest/pages/crc.aspx, diakses 26/11/2020. 
daerah, serta masyarakat dan keluarga untuk meningkatkan perlindungan kepada anak. ${ }^{33}$

Saat ini, upaya perlindungan terhadap anak semakin intensif dan mendapatkan perhatian yang lebih serius dari pemerintah terkait dengan sejumlah hal yang dapat mereduksi hak-hak anak. UU PA secara substantif mengatur sejumlah hal menyangkut masalah yang dihadapi anak. Satu di antaranya adalah perlindungan anak yang terlibat dalam jaringan terorisme. Konsep perlindungan anak berangkat dari asumsi bahwa anak adalah manusia yang memiliki hak yang sama untuk tumbuh dan berkembang.

Paradigma hukum (pidana) Indonesia menempatkan anak yang berhadapan dengan hukum sebagai "korban," termasuk mengenai anak yang terlibat dalam jaringan terorisme. Di sisi lain, terorisme sudah ditetapkan sebagai kejahatan luar biasa (extraordinary crime), sama dengan kejahatan narkotika dan korupsi. Namun, legislasi mengenai hal ini tampaknya kurang memperhatikan bahwa anak yang melakukan tidak pidana peredaran narkotika dan anak yang telibat dalam jaringan terorisme itu sebenarnya berbeda dalam hal akibat yang ditimbulkan pada diri anak. Berbeda dari tidak pidana narkotika, kejahatan terorisme bisa menyisakan ideologi ${ }^{34}$ pada diri anak yang sewaktu-waktu dapat hidup dan teraktualisasi dalam sebuah kejahatan (terorisme).

Berdasarkan pertimbangan tersebut, menyikapi anak yang terlibat dalam jaringan terorisme seperti ISIS, negara sejatinya

33 Hafrida, Nelli Herlina, dan Zulham Adamy, "The Protection of Women and Children as Victims of Human Trafficking in Jambi Province," Jambe Law Journal, 1, 2 (2019): 207-30.

34 Idelogi merupakan hal yang melekat dalam gerakan terorisme. Ideologi terorisme mengajarkan baha untuk melakukan perubahan sosial dan perubahan sistempolitikdapat ditempuhdenganjalankekerasan.Indrayanto, dkk., "Legal Policy for Returning Former ISIS Members of Indonesian Citizenship," Journal of Xi'an University of Architecture \& Technology, 12, 3 (2020), hlm. 3880. Ideologi menjadi salah satu pertimbangan mengapa terorisme dijadikan sebagai kejahatan luar biasa (extraordinary crime). Lihat Sri Yunanto, Angel Damayanti, dan Indah Novitasari, Ancaman dan Strategi Penanggulangan Terorisme di Dunia dan Indonesia (Jakarta: Institute For Peace and Security Studies dan CV. Multi Inovasi Mandiri, 2017), hlm. 2. 
memiliki suatu mekanisme yang memungkinkan anak dapat kembali normal (secara ideologis). Upaya yang paling rasional adalah deradikalisasi yang menjadi tugas utama dari Badan Nasional Penanggulangan Terorisme (BNPT). ${ }^{35}$ Lebih efektif sekiranya kerja-kerja deradikaliasi dilakukan melalui kerja sama dengan berbagai pihak, semisal RT/RW, LSM, tokoh adat, organisasi kepemudaan, organisasi keagamaan, lembaga pendidikan dan sebagainya. Tujuan kerjasama ini adalah memperluas wacana dan gerakan anti radikalisme di kalangan masayarakat luas hingga ke akar rumput. ${ }^{36}$

Hingga saat ini, payung hukum yang mengatur masalah anak yang terlibat dalam jaringan terorisme, seperti ISIS, secara khusus belum ada. Ketiadaan aturan spesifik mengenai masalah ini menyebabkan negara lalai terhadap hak-hak perlindungan anak, bahkan semena-semana sejauh menyangkut sikap negara terhadap anak yang terlibat dalam jaringan ISIS. Pengabaian terhadap hak asasi anak ini, pada gilirannya, menyebabkan nasib anak yang terlibat jaringan ISIS menjadi tidak jelas di hadapan negara.

Merujuk Khariroh Maknunah, persoalan utama dalam penanganan anak yang berkonflik dengan hukum terkait tindak pidana terorisme ialah sikap pemerintah yang mengabaikan hak-hak anak. Ia melaporkan, dalam proses penangkapan dan penyidikan hingga penahanan anak yang berkonflik dengan hukum dalam kasus tindak pidana terorisme, belum sesuai dengan semangat UU SPPA. Praktiknya, anak-anak yang berhadapan dengan hukum dalam tindak pidana terorisme tetap ditempatkan di lembaga pemasyarakatan dan belum dilakukan pembinaan secara maksimal di dalam lembaga tersebut. Selain itu, anak-anak tersebut ternyata ditempatkan

35 BNPT dibentuk dalam kapasitasnya sebagai lembaga yang menjalankan program deradikalisasi, yaitu suatu metode soft approach pembinaan terorisme. Salah satu upayanya adalah menerapkan syari'at Islam yang rahmatan lil alamin. Irfan Idris, Membumikan Deradikaliasi, Soft Approach Model Pembinaan Terorisme dari Hulu Ke Hilir Secara Berksenambungan (Jakarta: Daulat Press, 2017), hlm. 54.

36 Mohamad Rapik, Bunga Permatasari, dan Adinda Farah Anisya, "Peran Forum Koordinasi Pencegahan Terorisme dalam Menjalankan Program Deradikalisasi," Journal of Political Issues, 1, 2(2020), hlm. 112. 
bersama dengan orang dewasa yang juga merupakan narapidana terorisme. ${ }^{37}$ Padahal UU SPPA, Pasal 3 huruf b, melarang anak-anak yang berhadapan dengan hukum, termasuk dalam kasus tindak pidana terorisme, untuk ditempatkan bersama dengan orang dewasa, khususnya narapidana terorisme. Menempatkan anak bersama dengan orang dewasa kasus terorisme justru berpotensi besar untuk semakin mempertegas doktrin radikalisme yang mereka anut.

Prinsip utama penangan anak yang berkonflik dengan hukum adalah pradigma bahwa anak bukanlah untuk dihukum melainkan harus diberikan bimbingan dan pembinaan, sehingga bisa tumbuh dan berkembang sebagai anak normal yang sehat dan cerdas seutuhnya. ${ }^{38}$ Karena itu, UU SPPA mengharuskan dilakukannya upaya diversi ${ }^{39}$ melalui model restorative justice dalam proses pidana anak, termasuk dalam kasus terorisme. Pendekatan seperti ini sejalan dengan semangat deradikalisasi bagi anak yang berkonflik dengan hukum dalam tindak pidana terorisme. Cara lainnya adalah menempatkan anak pada Lembaga Pembinaan Khusus Anak (LPKA) yang dekat dengan keluarga mereka yang tidak terpapar paham radikal atau terorisme. Ini untuk memberi kesempatan bagi anak tersebut untuk tetap menjalin komunikasi dan merasakan suasana lingkungan yang normal, dan agar mendapatkan penerimaan dari masyarakat.

Di samping itu, UU PTPT diharapkan dapat mengakomodasi anak yang terafiliasi dengan jaringan terorisme lainnya. Di antaranya adalah anak dari para orang tua yang merupakan anggota jaringan terorisme, anak deportan eks ISIS, dan anak yang menempuh pendidikan di lembaga yang teraosiasi dengan radikalisme. Hal ini sangat urgen demi memberikan legitimasi yang kuat dalam upaya untuk melakukan pencegahan dan pemberantasan berikut penanganan tindak pidana terorisme di kalangan anak-anak. Guna mengakomodasi isu hukum ini, Undang-Undang Nomor 35 Tahun

37 Maknunah, Penanganan Anak dalam Tindak Pidana Terorisme.

38 Djamil, Anak Bukan Untuk Dihukum, hlm. 1.

39 Pasal 1 angka 7 Undang-Undang Nomor 11 Tahun 2012 tentang Sistem Peradilan Pidana Anak mendefinisikan diversi sebagai "pengalihan penyelesaian perkara anak dari proses peradilan pidana ke proses di luar peradilan pidana." 
2014 perubahan UU PA, terutama Pasal 69B, telah mengamanahkan upaya perlindungan ini. ${ }^{40}$ Tujuannya adalah agar dalam menangani anak yang berkonflik dengan hukum dalam tindak pianda terorisme, keselarasan dalam penerapan hukum dapat dicapai secara maksimal. ${ }^{41}$

Perlindungan anak adalah segala kegiatan untuk menjamin dan melindungi anak dan hak-haknya agar dapat hidup, tumbuh, berkembang, dan berpartisipasi, secara optimal sesuai dengan harkat dan martabat kemanusiaan, serta mendapat perlindungan dari kekerasan dan diskriminasi. Pasal 18 UU PA menyebutkan bahwa setiap anak yang menjadi korban atau pelaku tindak pidana berhak mendapatkan bantuan hukum dan bantuan lainnya.

Bukan hanya hukum nasional, perlindungan khusus terhadap anak juga menjadi perhatian dalam konvensi internasional, khususnya dalam situasi konflik dan perang. Bagi anak di bawah umur yang direkrut secara langsung oleh kelompok yang terlibat kejahatan teror ISIS, maka penangananya harus menerapkan prinsip peradilan anak. Hukuman pidana, seperti penjatuhan pidana penjara, sejatinya menjadi upaya terakhir.

Pemerintah Indonesia sudah menyusun Peraturan Pemerintah Pengganti Undang-undang (Perppu) Nomor 1 Tahun 2002 dan telah menjadi Undang-undang Nomor 15 Tahun 2003, yang kemudian diubah melalui Undang-Undang Nomor 5 Tahun 2018 tentang Pemberantasan Tindak Pidana Terorisme (UUPTPT). Langkah ini diambil pemerintah dalam upaya melindungi segenap warganya dan menciptakan situasi negara yang aman dan sejahtera dengan semangat menjaga kedaulatan bangsa dan negara. Namun, UU PTPT tersebut tidak memberikan pengaturan yang lebih jelas perihal anak yang terlibat kejahatan terorisme. Dalam UU ini, masalah anak yang terlibat dalam kejahatan terorisme hanya disebut dalam tiga pasal

40 Pasal 69B: "Perlindungan Khusus bagi Anak korban jaringan terorisme sebagaimana dimaksud dalam Pasal 59 ayat (2) huruf k dilakukan melalui upaya: a. edukasi tentang pendidikan, ideologi, dan nilai nasionalisme; b. konseling tentang bahaya terorisme; c. rehabilitasi sosial; dan $\mathrm{d}$. pendampingan sosial."

41 Maknunah, Penanganan Anak dalam Tindak Pidana Terorisme. 
saja, yaitu Pasal 16A, Pasal 19, dan Pasal 24. ${ }^{42}$

Dalam Pasal 16A UUPTPT (Perubahan) dinyatakan, "setiap orang yang melakukan Tindak Pidana Terorisme dengan melibatkan anak, ancaman pidananya ditambah satu per tiga”. Pasal 19 menyatakan "ketentuan mengenai penjatuhan pidana minimum khusus sebagaimana dimaksud dalam Pasal 6, Pasal 8, Pasal 9, Pasal 10, Pasal 11, Pasal 12, Pasal 13, Pasal 15, Pasal 16 dan ketentuan mengenai penjatuhan pidana mati atau pidana penjara seumur hidup sebagaimana dimaksud dalam Pasal 14, tidak berlaku untuk pelaku tindak pidana terorisme yang berusia di bawah 18 tahun”. Sedangkan Pasal 24 menyatakan "Ketentuan mengenai penjatuhan pidana minimum khusus sebagaimana dimaksud dalam Pasal 20, Pasal 21, dan Pasal 22, tidak berlaku untuk pelaku tindak pidana terorisme yang berusia di bawah 18 tahun".

Banyak yang menyarankan agar pemerintah meninjau ulang mengenai proses-proses yang ditempuh dalam menangani pelaku teroris dari kalangan anak-anak, terutama untuk diakomodasi dalam UU PTPT dan secara lebih rinci diimplementasikan ke dalam peraturan pemerintah lainnya. Ini merupakan langkah hati-hati yang harus dilakukan oleh pemerintah mengingat anak adalah korban dari tipu daya doktrin dan propaganda yang diintroduksi oleh orang-orang dewasa di sekelilingnya. UU PTPT sejatinya telah mengantisipasi hal ini dengan memasukkan ancaman bagi pidana terorisme bagi siapa saja yang dengan sengaja menggerakkan orang lain untuk melakukan tindak pidana terorisme, sebagaimana yang diatur dalam Pasal 14, terutama ajakan bagi anak-anak sebagaimana diatur pada Pasal 16A.

Sekalipun demikian, aturan mengenai posisi anak dalam tindak pidana terorisme sebagaimana yang terdapat pada tiga pasal tersebut jelas belum memadai. Hal ini terbukti dari sikap pemerintah yang kurang bisa memberikan kepastian hukum terkait masalah anakanak yang terlibat dalam jaringan terorisme. Keterbatasan jangkauan aturan yang menyinggung masalah ini, karenanya, adalah hal yang perlu dibenahi, yaitu dengan melakukan pembenahan terhadap

42 Peraturan Pemerintah Pengganti Undang-Undang Republik Indonesia Nomor 1 Tahun 2002 tentang Pemberantasan Tindak Pidana Terorisme. 
aturan perundang-undangan yang berkaitan dengan masalah ini. Ini demi mengantisipasi upaya-upaya kelompok teroris seperti ISIS untuk mejadikan anak-anak sebagai tumpuan harapan bagi perkembangan terorisme. ${ }^{43}$ Hukum harus bisa memberi jaminan bahwa anak-anak harus terbebas dari pengaruh paham radikal terorisme. Demikian pula, bila anak sudah terlanjur terlibat dalam jaringan terorisme, hukum harus mampu memberikan penanganan yang terbaik agar, di satu sisi dapat memberikan keadilan dan restorasi bagi si anak, namun di sisi lain tidak memberikan pengaruh buruk (secara ideologis) bagi anak lain. Harus diakui, meski belum dewasa, ternyata sebagian anak bekas anggota jaringan terorisme memiliki kemampuan untuk merekrut anggota dari kalangan anak-anak lainnya. Bahaya lain yang ditunjukkan oleh anak-anak eks anggota terorisme ini adalah perubahan perilaku yang cendrung abnormal dan tidak jarang melakukan tindak kekerasan. ${ }^{44}$ Tegasnya, diperlukan adanya reformulasi aturan yang lebih luas dan lebih konkrit berkenaan dengan perlindungan anak yang terlibat dalam jaringan terorisme, bukan hanya undang-undang terorisme, melainkan juga dalam undang-undang perlindungan anak dan undang-undang sistem peradilan pidana anak.

\section{Kesimpulan}

Permasalahan penanganan anak ISIS menunjukkan bahwa peme-

43 Sikap ini tidak berlebihan mengingat upaya-upaya ISIS, sebagaimana dilaporkan Quinton Temby, lebih mengintensifkan prekrutan pada perempuan dan anak-anak untuk dijadikan sebagai mujahid. Bagi ISIS, anakanak maupun perempuan lebih menarik dan lebih menjanjikan dibanding laki-laki dewasa. Tampilan polos anak-anak dan perempuan dianggap lebih cocok untuk mengelabui dibanding laki-laki dewasa. Bahkan, laki-laki dewasa sudah tidak menarik lagi untuk direkrut dalam aksi-aksi terorisme pada masa mendatang. Temby, Terrorism in Indonesia, hlm. 14-15.

44 Paśagić, "Between Child Soldiers, hlm. 113 dan 116-117. Untuk itu, agaknya perlu juga dipertimbangkan agar anak-anak yang berkonflik dengan hukum dalam tindak pidana terorisme diberikan perlakukan khusus dibanding anak-anak lain yang juga berkonflik dengan hukum. Jadi di samping menyediakan lembaga pemasyarakatan khusus anak, anak-anak dari jaringan terorisme itu juga harus dipisahkan dari anak-anak lain dan dilakukan pembinaan yang intensif. 
rintah belum memiliki panduan dan mekanisme yang jelas yang bisa dijadikan sebagai dasar yuridis. Sikap pemerintah lebih tampak sebagai kebijakan politis saja tanpa suatu panduan yang sifatnya lebih terukur. Penanganan yang diberlakukan terhadap anakyang berafiliasi dengan jaringan terorisme menunjukkan bahwa pemerintah masih ragu-ragu antara melindungi kepentingan anak dan menjaga stabilitas dan keamanan bangsa dan negara. Masalah lain terkait dengan penanganan anak ISIS adalah lemahnya instrumen hukum yang ada. Undang-undang yang ada, sesuai dengan paradigma perlindungan anak, telah berusaha memberikan sejumlah panduan legal formal berupa aturan-aturan yang memungkinkan anak dijauhkan dari peradilan pidana dan pemidanaan. Demikian juga, undang-undang yang ada berupaya memberi penekanan akan pentingnya posisi anak sebagai amanah dan karunia dari Tuhan Yang Maha Esa yang memiliki harkat dan martabat sebagai manusia yang seutuhnya. Namun, undang-undang yang ada tersebut tampaknya kurang mengantisipasi bagaimana norma hukum mengatur anak-anak yang terlibat dalam kejahatan extraordinary crime yang memiliki dampak destruktif yang luas. Ketidakjelasan pengaturan mengenai anak-anak dari jaringan terorisme menyebabkan timbulnya kesimpangsiuran mengenai pemaknaan dan penerapan paradigma "korban" terhadap anak yang terasosiasi dengan kelompok atau gerakan terorisme. Akibatnya banyak masyarakat yang mereka-reka menurut perasaan bahwa siapa pun yang terlibat dalam jaringan terorisme mesti dihukum seberat-beratnya. Ketakutan masyarakat bukan saja pada akibat fisik seperti pembunuhan yang bisa dilakukan oleh kelompok teroris, namun juga dampak ideologis yang sangat mungkin menyusup pasca kembalinya anak-anak (eks) ISIS ke tanah air. Karena itu, pemerintah sejatinya mampu memberikan kepastian hukum maupun kepastian dalam penerapannya agar keraguan dan kesimpangsiuran ini tidak memberikan kerugian bagi kedua belah pihak, yaitu anak ISIS maupun masyarakat luas. Selain itu, sebagai fungsi edukatif yang harus diberikan kepada anak ISIS, program deradikalisasi yang telah diamanatkan oleh undang-undang kepada badan, seperti BNPT harus dimaksimalkan agar anak-anak sebagai generasi masa depan 
tidak terpedaya dengan godaan dan bujuk rayu kelompok teroris apa pun. Adalah kewajiban negara melindungi segenap bangsa Indonesia dan seluruh tumpah darahnya dari segala ancaman kelompok teroris, seperti ISIS. Salah satu caranya ialah memperjelas aturan mengenai anak yang berhadapan hukum khususnya dalam perkara terorisme dalam peraturan perundang-undangan yang ada.

\section{Daftar Pustaka}

\section{Artikel, Buku, dan Laporan}

Arief, Akbar Mohmmad. "Terorisme dan Anak-Anak". https:// projectchild.ngo/blog/2020/01/15/terorisme-dan-anak-anak/, 15/01/2020. Diakses 04/03/2020.

Beritasatu.Com. "LPSK: Anak dan Istri Eks ISIS Bukan Korban". https: / / www.beritasatu.com / yuliantino-situmorang/ nasional / 600052/lpsk-anak-dan-istri-eks-isis-bukan-korban, 13/02/2020. Diakses 23/09/2020.

BBC News Indonesia. "Bisakah Kamu Memaafkan Ayah yang Jadi Anggota ISIS?”. https://www.youtube.com/ watch?v=GbjMdAFZhJk, 5/2/2020. Diakses 26/11/2020.

Darden, Jessica Trisko. Tackling Terrorists' Exploitation of Youth. Amerika: American Enterprise Institute, 2019.

Djamil, M. Nasir. Anak Bukan Untuk Dihukum Catatan Pembahasan UU Sistem Peradilan Pidana Anak (UU-SPPA). Jakarta: Sinar Grafika, 2013.

Hafrida, Nelli Herlina, dan Zulham Adamy. "The Protection of Women and Children as Victims of Human Trafficking in Jambi Province." Jambe Law Journal, 1, 2 (2019): 207-30. DOI: 10.22437 / jlj.1.2.207-230.

Hutagalung, Nurina Vidya. "Penanganan Anak Simpatisan ISIS". https: / / kolom.tempo.co/ read/1308827 / penanganan-anaksimpatisan-isis, 18/02/2020. Diakses 25/02/2020.

United Nations Office on Drugs and Crime. "The Bali Call for Action for the Implementation of the Unodc Roadmap on Children Associated with Terrorist and Violent Extremist Groups". 
https: / www.unodc.org/pdf/criminal_justice/endVAC/The_ Bali_Call_for_Action.pdf. Diakses 23/09/2020.

Idris, Irfan. Membumikan Deradikaliasi, Soft Approach Model Pembinaan

Terorisme dari Hulu Ke Hilir Secara Berksenambungan. Jakarta:

Daulat Press, 2017.

Indonesia Morning Show Net. "Menggunakan Senjata, Anak-anak Bocah ini Latihan Militer ISIS". https://www.youtube.com/ watch?v=14yVDKSdVNU, 24/5/2016. Diakses 03/03/2020.

Indrayanto, dkk. "Legal Policy for Returning Former ISIS Members of Indonesian Citizenship." Journal of Xi'an University of Architecture \& Technology, 12, 3 (2020): 3879-91.

Jones, Sidney. "How ISIS Has Changed Terrorism in Indonesia." The

New York Times, https://www.nytimes.com/2018/05/22/

opinion/isis-terrorism-indonesia-women.html, 22/05/2018.

Diakses 26/11/2020.

Kalla, Jusuf. "NIIS dan Janji Surga”. Harian Kompas, 12/12/2018.

Krähenmann, Sandra dan Paulien Vandendriessche. "From

Child Soldier to Child 'Terrorist': Safeguarding Innocence from Counter-terrorism”. https://blogs.icrc.org/lawand-policy/2019/11/20/ child-soldier-counter-terrorism/, 20/11/2019. Diakses 22/06/2020.

Mahyani, Ahmad. "Perlindungan Hukum Anak Sebagai Pelaku Terorisme." Jurnal Hukum Magnum Opus, 2 , 1 (2019): 47-54. DOI: 10.30996/jhmo.v2i2.2180.

Majalah Tempo. "Nestapa di Negeri Syam”. https: / majalah.tempo. $\mathrm{co} / \mathrm{read} / 157863 /$ nestapa-di-negeri-syam, 22/06/2019. Diakses $25 / 11 / 2020$

Maknunah, Khariroh. "Penanganan Anak dalam Tindak Pidana Terorisme”. Kertas Kebijakan RUU Nomor 15 Tahun 2003 tentang Penetapan Peraturan Pemerintah Pengganti UndangUndang Nomor 1 Tahun 2002 tentang Pemberantasan Tindak Pidana Terorisme Menjadi Undang-Undang, Indonesia Civil Society Against Violent Extremism. http://csave.org/wpcontent / uploads / 2018 / 06 / Penanganan-Anak-Dalam-TindakPidana-Terorisme.pdf?x96255. Diakses 26/11/2020. 
Nyamutata, Conrad. "Young Terrorists or Child Soldiers? ISIS Children, International Law and Victimhood." Journal of Conflict and Security Law, 25, 2 (2020): 236-61. DOI:10.1093/jcsl/krz034. Paśagić, Aleksandar. "Between Child Soldiers and Terrorists:

Reintegrating Child Members of the Islamic State.” Journal for Deradicalization, 20 (2019): 109-154.

Qodir, Zuly. HTI dan PKS Menuai Kritik: Perilaku Gerakan Islam Politik Indonesia. Yogyakarta: Universitas Muhammadiyah, 2013.

Rapik, Mohamad, Bunga Permatasari, dan Adinda Farah Anisya.

"Peran Forum Koordinasi Pencegahan Terorisme dalam Menjalankan Program Deradikalisasi." Journal of Political Issues, 1, 2 (2020): 103-114. DOI: 10.33019/jpi.v1i2.11.

Rasyid, Makmum. Hizbut Tahrir Indonesia: Gagal Faham Khilafah.

Ciputat: Pustaka Compass, 2016

Rijal, Najamuddin Khairur. "Eksistensi dan Perkembangan ISIS: Dari

Irak Hingga Indonesia”. Jurnal Ilmiah Hubungan Internasional, 13, 1 (2017): 45-60. DOI: 10.26593/jihi.v13i1.2670.45-60.

Rondonuwu, Grover. "Memulangkan Pejuang ISIS Eks WNI, Dilema Hukum dan Kemanusiaan”. https://www. kompasiana.com/grover/5e3c96c2d541df7bcd6d9f62/ memulangkan-pejuang-isis-eks-wni-dilema-hukum-dankemanusiaan?page $=$ all\#sectionall, $\quad 7 / 2 / 2020 . \quad$ Diakses $25 / 2 / 2020$.

Sahid HM. "Contesting Caliphate: Opposition of Indonesian Fundamentalist Groups to ISIS Caliphate.” Journal of Indonesian Islam, Vol 8 No 2 (2014): 185-208. DOI: 10.15642/JIIS.2014.8.2.185208.

Samu, Kifly Arafat. "Status Hukum Warga Negara Indonesia yang Terlibat dalam Organisasi Teroris Internasional”. Lex Et Societatis, 6, 10 (2018: 75-84.

Sarwono, Sarlito Wirawan. Terorisme di Indonesia dalam Tinjauan Psikologi. Ciputat: Pustaka Alvabet, 2012.

Santoso, Bambang, Soehartono, dan Muhammad Rustamaji. "Unearthing the Philosophical Roots of Pancasila on Distinctive Legal Treatments for Children in Conflict with the Law." Yustisia, 
6, 2 (2017): 288-301. DOI: 10.20961/yustisia.v6i2.12412.

Schulze, Kirsten E. "The Surabaya Bombings and the Evolution of the Jihadi Treat in Indonesia." CTC Sentinel, 11, 6 (2018): 1-6.

Temby, Quinton. Terrorism In Indonesia After "Islamic State". Singapore: ISEAS-Yusof Ishak Institute, 2020.

United Nations Human Rights Office of the High Commissioner. "Convention on the Rights of the Child". https://www. ohchr.org/en/professionalinterest/pages/crc.aspx. Diakses $26 / 11 / 2020$.

United Nations Office on Drugs and Crime. Handbook on Children Recruited and Exploited by Terrorist and Violent Extremist Groups: The Role of the Justice System. Vienna: United Nations, 2017. Wahid, Abdul, Sunardi, dan Muhammad Imam Sidik. Kejahatan Terorisme: Perspektif Agama, HAM, dan Hukum. Bandung: Refika Aditama, 2004.

Yunanto, Sri, Angel Damayanti, dan Indah Novitasari. Ancaman dan Strategi Penanggulangan Terorisme di Dunia dan Indonesia. Jakarta: Institute For Peace and Security Studies dan CV. Multi Inovasi Mandiri, 2017.

\section{Peraturan Hukum}

Republik Indonesia. Undang-Undang Nomor 11 Tahun 2012 tentang

Sistem Peradilan Pidana Anak. Lembaran Negara Tahun 2012

Nomor 153, Tambahan Lembaran Negara Nomor 5332.

Republik Indonesia. Undang-Undang Nomor 35 Tahun 2014 tentang

Perubahan atas Undang-undang Nomor 23 Tahun 2002 tentang Perlindungan Anak. Lembaran Negara Tahun 2014 Nomor 297, Tambahan Lembaran Negara Nomor 5606.

Republik Indonesia. Undang-Undang Nomor 5 Tahun 2018 tentang Perubahan atas Undang-Undang Nomor 15 Tahun 2003 tentang Penetapan Peraturan Pemerintah Pengganti Undang-Undang Nomor 1 Tahun 2002 tentang Pemberantasan Tindak Pidana Terorisme Menjadi Undang-undang. Lembaran Negara Tahun 2018 Nomor 92, Tambahan Lembaran Negara Nomor 6216. 